\title{
A date for volcanic eruption inferred from a siltstone xenolith
}

\author{
Yue-Gau Chen*, Wen-Shoung Wu, Cheng-Hong Chen, Tsung-Kwei Liu \\ Department of Geology, National Taiwan University, 245 Choushan Road, Taipei 106, Taiwan, Republic of China
}

\begin{abstract}
We present a TL age determination of a heated siltstone xenolith found at Kueishantao, a volcanic island $10 \mathrm{~km}$ off the northeastern shoreline of Taiwan. Before this study, no reliable numeric age determination had been obtained for the volcanic rocks. Its age has long been desired due to its active tectonic environment. Previous studies of the other radiometric dating methods indicate a very young age for the eruption of this volcano, possibly later than $10 \mathrm{ka}$. However, reliable age is not allowed because it is younger than the lower dating limit. Our result shows a TL age of $7 \pm 0.7 \mathrm{ka}$ for the lower part of the volcanic sequence, indicating that other volcanic eruptions occurred later than $7 \mathrm{ka}$. This finding suggests that the volcanic island, Kueishantao, has not ceased its igneous activity and is still active geologically. (C) 2000 Elsevier Science Ltd. All rights reserved.
\end{abstract}

\section{Introduction}

Except for a few recent cases (Nairn et al., 1995; Chen et al., 1996; Renne et al., 1997), it has long been a difficult job to determine the age of a Holocene volcanic rock. The reason is not only that the Holocene age is too young to be analyzed by $\mathrm{Ar}-\mathrm{Ar}$ and $\mathrm{K}-\mathrm{Ar}$ methods, but also that difficulty will be encountered in finding suitable material for the ${ }^{14} \mathrm{C}$ as well as the $\mathrm{U}-\mathrm{Th}$ method. The thermoluminescence (TL) method is able to determine a Holocene age, especially for baked samples, such as pottery or tuff (Zimmerman, 1971; Fleming, 1979; Aitken, 1985). To avoid the anomalous fading (Wintle, 1973; Tyler and Mckeever, 1988; Berger, 1992), sediments dominated by quartz fraction seem to be advantageous; however, TL age is questioned by uncertain sunlightbleached residue (Singhvi and Mejdahl, 1985; Forman, 1988, 1989). Accordingly, a sedimentary rock xenolith embraced in volcanic rocks, subjected to a baking history, has been treated as a good material, if the major minerals (i.e., quartz) remain not fused. For instance, the maximum experienced temperature of the andesitic volcanic rock is usually lower than melting point of quartz; thus, it is a good proxy to tell the cooling age of the volcano.

\footnotetext{
Paper published in December 2000.

* Corresponding author. Tel.: + 886-2-2363 ext.-0231-2672; fax: $+886-2-2363-6095$.

E-mail address: ygchen@ccms.ntu.edu.tw (Y.-G. Chen).
}

\section{Geology background}

Kueishantao is a volcanic island, composed of andesite including lava flow and pyroclastics (Chen, 1990). It is located at a tectonic conjunction of the extension of the fault system of Taiwan and the southern rifting end of the Okinawa Trough, a current back-arc rifting depression of the Ryukyu arc-trench system (Letouzey and Kimura, 1985; Kizaki, 1986; Sibuet et al., 1987, Lee and Wang, 1988; Teng, 1996; Fig. 1). On the basis of geological and geophysical investigations, the opening history of the Trough has been identified as having two to three phases (Miki, 1995; Sibuet et al., 1998). The latest phase is ongoing, which is evidenced by high heat flow, dense earthquakes and active hydrothermal mounds (Eguchi and Uyeda, 1983; Kimura et al., 1988; Yamano et al., 1989; Kinoshita and Yamano, 1997). In short, the abovementioned two tectonic mechanisms cause a complicated current situation around the Kueishantao. Thus, the area around Kueishantao is tectonically active and the knowledge of eruption ages of the volcanic island is urgently needed because of the high density of nearby population.

Based on stratigraphical investigation, the exposed volcanic strata can be preliminarily divided into several units. The lowest one is a massive lava flow, characterized by scattered sedimentary xenoliths, which are probably derived from the surrounding sedimentary strata. The thickness of this unit remains unknown due to invisible lower boundary. Its overlying unit is pyroclastic lahar, characterized by miscellaneous andesitic and scattered sedimentary fragments, which are identified as the 


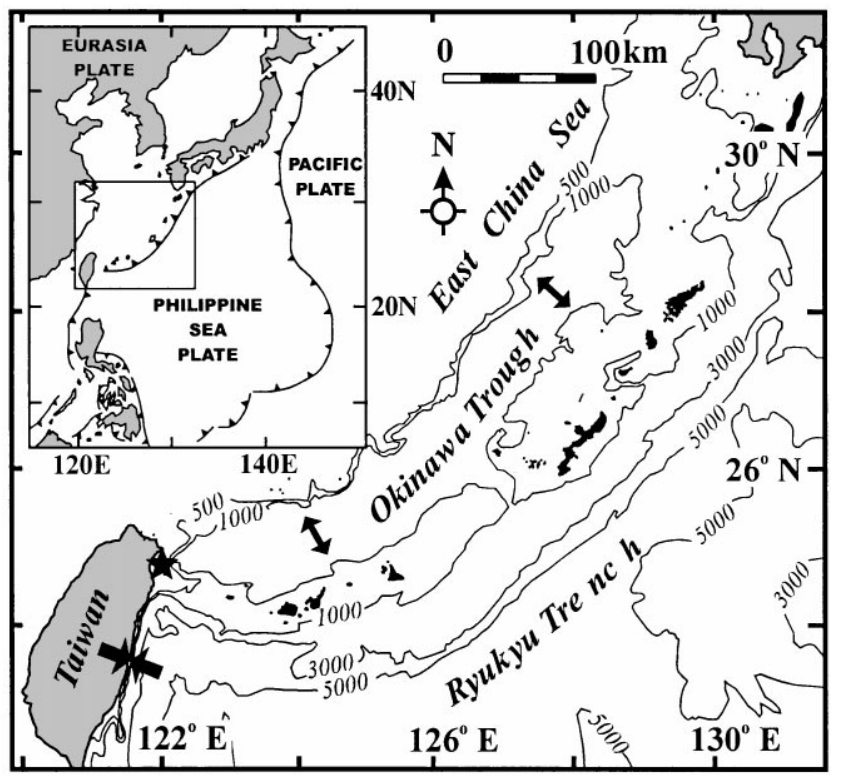

Fig. 1. Map showing the geography surrounding the Okinawa Trough. The Kueishantao volcano (black star) is located at its southwestern tip, very close to northeast coast of Taiwan. The black arrows mark the major relative plate movements. The inset figure shows the modern tectonic relationship around the west Pacific.

same as the xenoliths found in the underlying lava flow. Thus, they inevitably experienced a heating history as did their host igneous rock. We collected the dating material from this unit due to the interests of sample quality. Above the second unit, there are still a few more covering andesitic lava flow units.

\section{Chronlogy and TL dating}

Previously, Juang and Chen (1989) have determined the age of andesite collected from Kueishantao using the $\mathrm{K}-\mathrm{Ar}$ method. Their result showed an age of $0.02 \pm 0.01 \mathrm{Ma}$, which only can allow us to understand that the Kueishantao must be very young. Another study using U-Th method to determine the ages of pumices collected around the southern Okinawa Trough revealed three eruption pulses in this area (Chen et al., 1993). They are 10,30 , and $70 \mathrm{ka}$, respectively. Although both approaches gave constraints on the timing of volcanic eruptions in southern Okinawa Trough, still no precisely numeric age was achieved for the volcanic island - Kueishantao. When we failed to find any possible carbonaceous material in the strata, a number of the sedimentary xenoliths were collected instead. Since the sedimentary xenolith was supposedly subjected to a baking history, TL dating method is able to serve us to approximate the eruption age of Kueishantao.
TL method can provide reliable Holocene ages for pottery samples, in which the linear regression of additive-dose method can afford us a very good precision and accuracy (Aitken, 1985). This is because the unstable luminescence centers (i.e., easily saturated ones) are minimized due to the heat associated with pottery making (Zimmerman, 1971; Fleming, 1979; Aitken, 1985). Sedimentary xenoliths found in acidic volcanic rocks had been subjected to a heating temperature we supposed to be equivalent to that which pottery undergoes. This indicates that such a xenolith is a good material for TL dating.

The sedimentary xenolith found in Kueishantao, likely was the right target as mentioned above. Because of the silty-grain texture of the xenolith, we chose the fine-grain multi-aliquots method to pretreat the raw sample. Using an acetone suspension we evenly deposited the drilled powders on aluminum discs of $1 \mathrm{~cm}$ in diameter. Totally, over 50 discs were prepared at the same time. For each datum we analyzed three of them and then made an average value. First of all, we utilized 12 discs for anomalous fading test. After artificial radiation exposure, 4-5\% TL intensity significantly decreased within the first three days; however, no detectable loss was found from the fourth day to one month later. To avoid the interference of anomalous fading, every measurement was intended to delay three days. Based on preliminary tests, the additional radiation conducted from 10 to $50 \mathrm{~Gy}$ with interval of $10 \mathrm{~Gy}$ gave the optimum resolution (Fig. 2). Based on the shape of glow curves and the plateau test (Fig. 2b), temperature interval of $340-360^{\circ} \mathrm{C}$ was chosen to integrate the TL intensity for equivalent dose (ED) regression (Fig. 3). In addition, second-glow regression shows a very small correction value for supra-linearity, representing that it can be ignored. We then directly treated the ED $28.1 \mu \mathrm{Gy} / \mathrm{yr}$ to be the paleo-dose for age calculation. A further ED plateau test, conducted to recheck the above temperature region selection, indicates that $340-360^{\circ} \mathrm{C}$ is indeed a stable region and suggests that our result is acceptable (Fig. 3b). Test duplications for the same and different xenoliths demonstrated very close results (Table 1). This further suggests that the age determination is quite reliable. For the annual dose calculation, the sedimentary xenolith and volcanic host rock were both analyzed for $\mathrm{U}$, Th, and $\mathrm{K}$ contents by ICPmass spectromery and X-ray fluorescence method (Table 1). We assumed the water content was zero and no radon loss occurred due to its compact characteristics. Also, we assumed $\alpha$ and $\beta$ come from xenolith itself and $\gamma$ has two sources: from xenolith and its surrounding materials. Therefore, the thickness of the sample has to be measured for $\gamma$ efficiency correction for the outside source (Aitken, 1985). The $\alpha$ efficiency factor $(k)$ was conducted by another disc set, prepared at the same time with those for ED derivation. The contribution of cosmic rays was applied by $150 \mu \mathrm{Gy} / \mathrm{kyr}$ that is the value of burial depth 

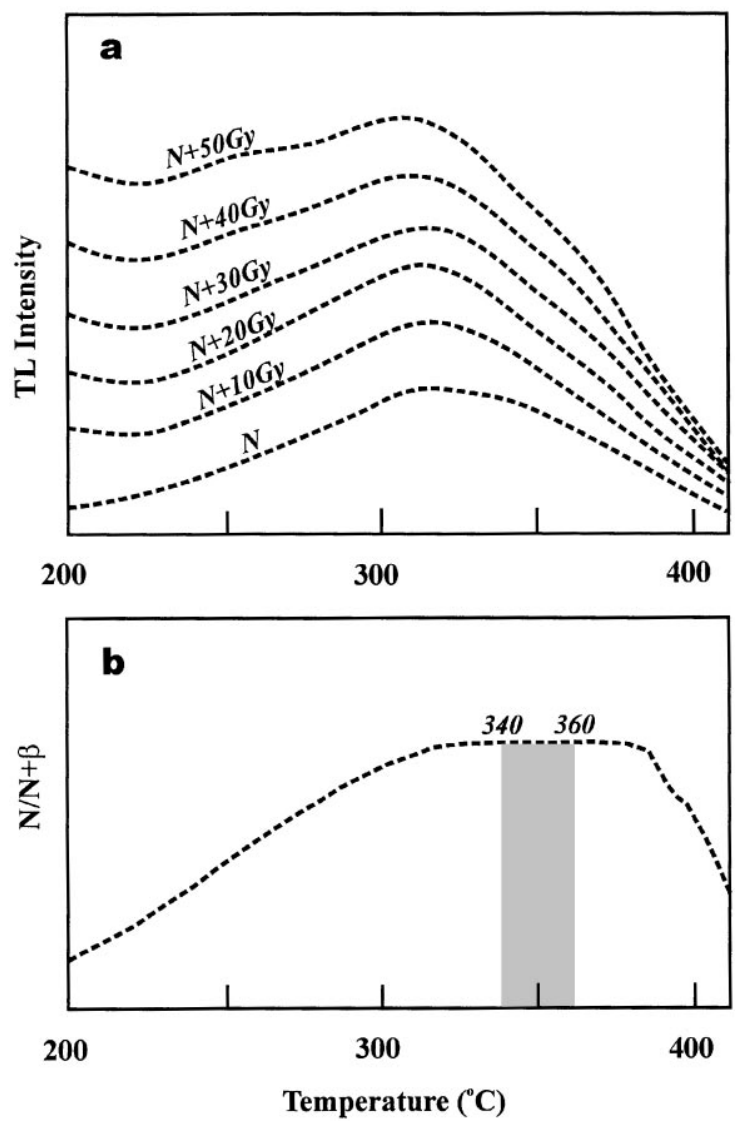

Fig. 2. (a) Glow curves (dash lines) show a signal peak occurring at around $320^{\circ} \mathrm{C}$. The $\mathrm{N}$ marked curve is the one derived from natural sample. The other are curves after exposure under artificial radiation with additive dose of 10, 20,30, 40 and $50 \mathrm{~Gy}$. (b) The linear-response plateau test (dash curve) derived by $\mathrm{N} / \mathrm{N}+\beta$ shows a stable temperature region from 320 to $380^{\circ} \mathrm{C}$.

around $1 \mathrm{~m}$ (Aitken, 1985; Prescott and Hutton, 1988). As we know, the intensity of cosmic rays decrease significantly when burial depth increases (Aitken, 1985); however, our sampling site is close to sea-level and on the surface. Thus, we assume that it is not necessary to further correct the cosmic ray intensity. All the correction factors are shown in Table 1 and the computed annual dose is $4.04 \mu \mathrm{Gy} / \mathrm{yr}$. Finally, a TL age of around $7 \mathrm{ka}$ can be simply derived. The analytical error could be separately estimated for paleo-dose and annual dose. For the paleo-dose regression, the working error is lower but close to $3 \%$ including uncertainties from sample preparation and instrumental analysis. For the annual dose, both of two well-developed analytical methods, i.e., XRF and ICP mass spectrometry, generally yield errors lower than $2 \%$; however, we usually raise it up to $5-7 \%$ when considered the other error sources, such as the sample heterogeneity and correction factor derivations. In summary, a total error for our age was conservatively given as $10 \%$ or so.

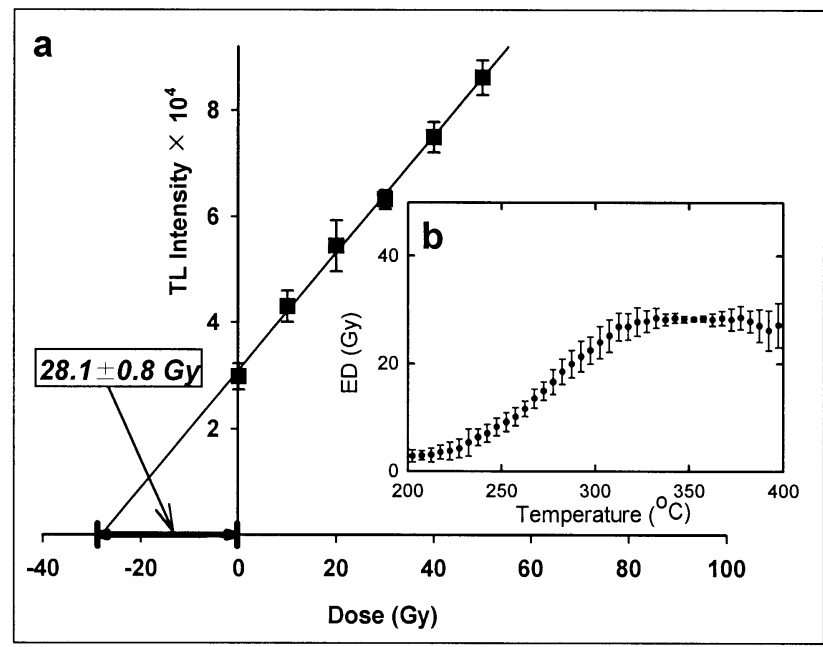

Fig. 3. (a) Data points representing signals integrated from 340 to $360^{\circ} \mathrm{C}$ are well fitted by a straight-line regression. The derived ED value is $28.1 \pm 0.8 \mathrm{~Gy}$. (b) The ED plateau test, derived by temperature interval of $5^{\circ} \mathrm{C}$, demonstrates a flat region higher than $320^{\circ} \mathrm{C}$, especially around $350^{\circ} \mathrm{C}$. Error bars are $\pm 1 \sigma$.

\section{Result and discussion}

A Holocene volcano has been commonly categorized as an active volcano (Szakacs, 1994). Since Kueishantao has been determined as a Holocene volcano in this study and the dated rock unit is not the latest one according to our field observation, we must pay attention on such a volcano. A further review of the relevant volcanisms around this area might be helpful for understanding the recurrence probability. As early as 1985, Letouzey and Kimura reported numerous Pleistocene and present magmatic activities in the Okinawa Trough; however, they were mainly distributed in the northern Trough. More recently, Wang (1998) used the Ar-Ar method to analyze several basalts and ryolites dredged from the central Trough and documented three ages younger than $100 \mathrm{ka}$. This result probably indicates that the current volcanic activity is not only confined to the northern Trough. On the other hand, post-collisional extension was proposed to increase the magmatism of northern Taiwan since the Quaternary (Wang et al., 1999), representing a high potentiality of volcanism in this region. Since such a geological environment surrounds the Kueishantao, we believe that probably it will erupt again. Furthermore, it is nearly attached to a densely populated coastal area, the northeastern coast of Taiwan. Scientific studies with respect to volcanic activities must be launched before long to establish the details.

\section{Conclusion and remark}

This study successfully determined a Holocene age of a volcano by TL method on a siltstone xenolith. The 
Table 1

Parameters for annual dose derivation and age calculation

\begin{tabular}{|c|c|c|c|c|c|c|c|c|}
\hline $\mathrm{U}_{\mathrm{x}}{ }^{\mathrm{a}}(\mathrm{ppm})$ & $\mathrm{Th}_{\mathrm{x}}(\mathrm{ppm})$ & $\mathrm{K}_{\mathrm{x}}(\%)$ & $\mathrm{U}_{\mathrm{h}}(\mathrm{ppm})$ & $\mathrm{Th}_{\mathrm{h}}(\mathrm{ppm})$ & $\mathrm{K}_{\mathrm{h}}(\%)$ & $k$-value & $P$-value & $t^{\mathrm{b}}(\mathrm{cm})$ \\
\hline 1.97 & 14.72 & 1.44 & 1.75 & 8.70 & 1.95 & 0.05 & 28.82 & 4.00 \\
\hline Water $(\%)$ & $\begin{array}{l}\text { Radon loss } \\
(\%)\end{array}$ & $\begin{array}{l}\alpha \text { dose } \\
(\mathrm{Gy} / \mathrm{kyr})\end{array}$ & $\begin{array}{l}\beta \text { dose } \\
(\mathrm{Gy} / \mathrm{kyr})\end{array}$ & $\begin{array}{l}\gamma \text { dose } \\
(\mathrm{Gy} / \mathrm{kyr})\end{array}$ & $\begin{array}{l}\text { Cosmic ray } \\
(\mathrm{Gy} / \mathrm{kyr})\end{array}$ & $\begin{array}{l}\text { Annual dose } \\
(\mathrm{Gy} / \mathrm{kyr})\end{array}$ & $\begin{array}{l}\text { Equivalent dose } \\
(\mathrm{Gy} / \mathrm{kyr})\end{array}$ & Age (ka) \\
\hline zero $^{c}$ & none $^{\mathrm{c}}$ & 0.80 & 1.91 & 1.18 & 0.15 & 4.04 & $28.1\left(4^{\mathrm{d}}\right)$ & 7.0 \\
\hline
\end{tabular}

a Subscripts $\mathrm{x}$ and $\mathrm{h}$ represent xenolith and host rock, respectively.

${ }^{\mathrm{b}} t$ is the thickness of dating material if it is pottery (Aitken, 1985). Our material is a disc-like siltstone, thus we applied the same parameter for annual dose derivation.

${ }^{\mathrm{c}}$ Due to the compact characteristics, we assumed that the water content is zero and no radon loss as well.

${ }^{\mathrm{d}}$ Number represents the repetition time for the ED determination of target xenolith. The reported value of 28.1 is an average of $28.4,28.3,28.1$, and 27.6. Another collected xenolith gave a very close ED of 27.8. Due to the quality, we prefer to only report the first one.

method has many advantages, such as linear TL intensity growth, very low anomalous fading, no initial value problem, etc. Our age result reveals that a Holocene volcanic island is located at near shore area of northeastern Taiwan, where is densely populated. Further monitoring for the volcanic activities is urgently necessary. Furthermore, it is expected that this method can help scientists to find new evidence for the volcanism that was not previously accessible.

\section{Acknowledgements}

The authors thank all the scientists and assistants for their help in field and laboratory. This study was supported by National Science Concil, Taiwan, Republic of China under Grant Nos. NSC-84-2111-M-002-028 and NSC-85-2111-M-002-042.

\section{References}

Aitken, M.J., 1985. Thermoluminescence Dating. Academic Press, London, $359 \mathrm{pp}$.

Berger, G.W., 1992. Dating volcanic ash by use of thermoluminescence. Geology 21, 11-14.

Chen, C.-H., 1990. Igneous Rocks in Taiwan. Central Geological Survey, Ministry of Economic Affairs, People's Republic of China, 137 pp. (in Chinese).

Chen, L.R., Zhuai, S.K., Shen, S.X., 1993. Isotopic characteristics and age determination of pumices from Okinawa Trough. Science in China 23 (3), 324-329 (in Chinese).

Chen, Y.S., Smith, P.E., Evensen, N.M., York, D., Lajoie, K.R., 1996. The edge of time: dating young volcanic ash layers with the ${ }^{40} \mathrm{Ar}-{ }^{39} \mathrm{Ar}$ laser probe. Science $274,1176-1178$.

Eguchi, T., Uyeda, S., 1983. Seismotectonics of the Okinawa Trough and Ryukyu arc. Memoirs of the Geological Society of China 5, 189-210.

Fleming, S.L., 1979. Thermoluminescence techniques in archaeology. Clarendon Press, Oxford, 233 pp.
Forman, S.L., 1988. The solar resetting of thermoluminescence of sediments in a glacier dominated fiord environment in Spotsbergen: geochronologic implication. Arctic and Alpine Research 20, 243-253.

Forman, S.L., 1989. Applications and limitations of Thermoluminescence to date Quaternary sediments. Quaternary International 1, 47-59.

Juang, W.S., Chen, J.C., 1989. Geochronology and geochemistry of volcanic rocks in northern Taiwan. Bulletin of the Central Geological Survey 5, 31-66 (in Chinese).

Kimura, M., Uyeda, S., Kato, Y., Tanaka, T., Yamano, M., Gamo, T., Sakai, H., Kato, S., Izawa, E., Oomori, T., 1988. Active hydrothermal mounds in the Okinawa Trough backarc basin Japan. Tectonophics 145, 319-324.

Kinoshita, M., Yamano, M., 1997. Hydrothermal regime and constrains on reservoir depth of the Jade site in the Mid-Okinawa Trough inferred from heat flow measurements. Journal of Geophysical Research 102 (B2), 3183-3194.

Kizaki, K., 1986. Geology and tectonics of the Ryukyu Islands. Tectonophysics $125,193-207$.

Lee, C.T., Wang, Y., 1988. Quaternary stress changes in northern Taiwan and their tectonic significance. Proceedings of the Geological Society of China 31 (1), 154-168.

Letouzey, J., Kimura, M., 1985. Okinawa Trough genesis: structure and evolution of a backarc basin developed in a continent. Marine and Petroleum Geology 2, 111-130.

Miki, M., 1995. Two-phase opening model for the Okinawa Trough inferred from paleomagnetic study of the Ryukyu arc. Journal of Geophysical Research 100 (B5), 8169-8184.

Nairn, I.A., McKee, C.O., Talai, B., Wood, C.P., 1995. Geology and eruptive history of the Rabaul Caldera area. Papua New Guinea. Journal of Volcanology and Geothermal Resrarch 69, 255-284.

Prescott, J.R., Hutton, J.T., 1988. Cosmic ray and gamma ray dosimetry for TL and ESR. Nuclear Tracks and Radiation Measurements 14, 223-227.

Renne, P.R., Sharp, W.D., Deino, A.L., Oris, G., Civetta, L., 1997. ${ }^{40} \mathrm{Ar} /{ }^{39} \mathrm{Ar}$ dating into the historical realm: calibration against Pliny the younger. Science 277, 1279-1280.

Sibuet, J.-C., Deffontaines, B., Hsu, S.K., Thareau, N., LeFormal, J.-P., Lallemand, S., Liu, C.S., 1998. Okinawa Trough backarc basin: early tectonic and magmatic evolution. Journal of Geophysical Research 103 (B12), 30 245-30 267.

Sibuet, J.-C., Letouzey, J., Barbier, F., Charvet, J., Fourcher, J.-P., Hilde, T.W.S., Kimura, M., Chiao, L.-Y., Marsset, B., Muller, C., Stephan, J.-F., 1987. Back Arc Extension in the Okinawa Trough. Journal of Geophysical Research 92 (B13), 14041-14063. 
Singhvi, A.K., Mejdahl, V., 1985. Thermoluminescence dating of sediments. Nuclear Tracks 10, 137-161.

Szakacs, A., 1994. Redefining active volcanoes: a discussion. Bulletion of Volcanology 56, 321-325.

Teng, L.S., 1996. Extensional collapse of the northern Taiwan mountain belt. Geology 24, 949-952.

Tyler, S., Mckeever, S.W.S., 1988. Anomalous fading of thermoluminescence in oligoclase. Nuclear Tracksacid Radiation Measurements $14,149-154$.

Wang, H.L., 1998. Ar-Ar dating and geochemistry of volcanic rocks dredged from the middle Okinawa Trough. Master Dissertation, Department of Geology, National Taiwan University, unpublished, 119 pp. (in Chinese).
Wang, K.L., Chung, S.L., Chen, C.H., Shinjo, R., Yang, T.F., Chen, C-H., 1999. Post-collisional magmatism around northern Taiwan and its relation with opening of the Okinawa Trough. Tectonophysics 308, 363-376.

Wintle, A.G., 1973. Anomalous fading of thermoluminescence in mineral samples. Nature 245, 143-144.

Yamano, M., Uyeda, S., Foucher, J.P., Sibuet, J.C., 1989. Heaat flow anomaly in the middle Okinawa Trough. Tectonophysics 159, 307-318.

Zimmerman, D.W., 1971. Thermoluminescence dating using fine grains from pottery. Archaeometry 13, 29-52. 